TARBIYATUNA: Kajian Pendidikan Islam

Volume 3 Nomor 2 Tahun 2019

Print ISSN : 2597-4807

Online ISSN : 2622-1942

\title{
STRATEGI KIAI DALAM MENSUKSESKAN PEMBELAJARAN NAHWU DAN SHOROF DI PONDOK PESANTREN AL-BIDAYAH TEGALBESAR KALIWATES JEMBER
}

\author{
Imam Wahyono \\ Fakultas Tarbiyah, Institut Agama Islam Ibrahimy Genteng Banyuwangi \\ e-mail: imamwahyono12031989@gmail.com
}

\begin{abstract}
In studying the yellow book (kitab kuning) there is at least grammatical science that must be learned by a student, namely the science of Nahwu and Shorof. But in reality for the majority of students studying both sciences is a scourge. This is because in learning science nahwu and shorof there are many terms that seem difficult to understand. To induce the learning of nahwu and shorof, of course the existence of the kiai in determining his learning strategy is very important so that the presumption of learning nahwu and shorof that seems difficult can be easy.

This study aims to determine the strategy of the kiai in inducing learning from nahwu and shorof at Al-Bidayah Islamic Boarding School in Tegalbesar Kaliwates Jember. The method used in this study uses a descriptive qualitative research approach. The data collection techniques using interviews, observation and documentation using purposive sampling in determining research subjects. Data analysis and checking the validity of the data in this study used the theory put forward by Miles and Huberman. In testing the validity of the data obtained, researchers used a triangulation technique.

This research has concluded that the kiai in the success of nahwu and shorof learning use two strategies, namely the learning method and the preparation of textbooks. The method that is often used is the Wetonan method, sorogan and memorization (hafalan) as traditional methods and peer tutorial methods as modern methods. The preparation of textbooks done by the kiai is a new breakthrough because this book is arranged systematically so that it is easy to understand, digest and understand by students.
\end{abstract}

Keywords: Strategy of the kiai, the science of Nahwu and Shorof

\begin{tabular}{|c|c|c|}
\hline Accepted: & Reviewed: & Publised: \\
Juli 262019 & Agustus 18 2019 & September 30 2019 \\
\hline
\end{tabular}

This work is licensed under Creative Commons Attribution Non Commercial 4.0 International License Available iaiibrahimy.ac.id 


\section{A. Pendahuluan}

Secara historis, pesantren merupakan lembaga pendidikan keagamaan tertua di Indonesia yang eksis jauh sebelum negara ini merdeka. Sebagai lembaga pendidikan tertua, pesantren memiliki karakteristik yang berbeda dan sangat unik dalam implementasi sistem pendidikan pondok pesantren khususnya dalam menerapkan kurikulum kitabi (baca: kitab kuning) (Noor: 2006: xvii).

Dalam sejarah perkembangan pendidikan di pondok pesantren, para pakar berpendapat bahwasanya antara pesantren dan kitab kuning merupakan dua hal yang tidak bisa terpisahkan di samping adanya kiai, santri asrama dan masjid. Karena kitab kuning merupakan pelajaran yang wajib hukumnya untuk dipelajari bagi semua santri tanpa terkecuali

Melihat betapa pentingnya keberadaan kitab kuning di kalangan pondok pesantren, setidaknya ada beberapa statemen yang harus dipahami dan dicermati. Pertama, berdasarkan cara pandang masyarakat, Kitab kuning dianggap sebagai kitab pusaka yang sakti mandraguna yang harus diturunkan secara turun temurun sebagai bacaan utama yang wajib dikuasai masyarakat pesantren secara luas. Kedua, kitab kuning berfungsi sebagai referensi penting dalam menyikapi problematika kehidupan sehari-hari sampai saat ini. Ketiga, kalau ditelisik lebih dalam lagi, kitab kuning merupakan kitab yang dinamis yang merupakan transfer pembentukan tradisi keilmuan fikih sufistik yang didukung penguasaan ilmu-ilmu instrumental. Keempat, kitab kuning dipilih menjadi referensi utama di pondok pesantren terkait dengan perkembangan Intelektual Islam Nusantara (Wahyono, 2017).

Mengingat betapa pentingnya keberadaan kitab kuning tersebut, Kementrian Agama melalui PMA No. 13 Tahun 2014 tentang Pendidikan Keagamaan Islam Pasal 5 menjelaskan bahwa "Pesantren wajib memiliki unsurunsur pesantren yang salah satunya adalah pengajian atau kajian kitab kuning atau dirasah islamiyah dengan pola mu'allimin. Pemerintah dalam hal ini Kementerian Agama telah turut serta dalam upaya pengembangan pesantren dalam bentuk dukungan regulasi, bantuan sarana dan prasarana serta kegiatan pengembangan. Kegiatan pengembangan tersebut yaitu pelaksanaan Musabaqah Qiraatil Kutub (Lomba Baca Kitab Kuning), serta adanya bantuan berupa kitabkitab kuning dalam judul tertentu yang didistribusikan ke beberapa pesantren" (PMA NO Nomor 13 Tahun 2014 tentang Pendidikan Keagamaan Islam).

Untuk mensukseskan pembelajaran kitab kuning tersebut, tentu keberadaan kiai atau pengasuh sangat menentukan. Hal ini terlihat sangat jelas pada penerapan pembelajaran kitab kuning saat ini, bahwasanya tidak sedikit 
pondok pesantren yang tidak berkembang dan kurang diminati masyarakat ketika seorang kiai tidak memiliki strategi yang jitu dalam pembelajaran kitab kuning di pondok pesantrennya.

Pembelajaran kitab kuning merupakan kegiatan pembelajaran terhadap kitab-kitab keagamaan berbahasa arab atau berhuruf arab oleh kiai sebagai pengajar kepada para santri dengan metode-metode tertentu untuk tercapainya tujuan yang telah ditetapkan dalam kurikulum. Ada dua esensial tujuan dalam pembelajaran kitab kuning yang diajarkan kepada para santri di pondok pesantren yaitu disamping mempelajari isi kitab, maka secara tidak langsung juga mempelajari bahasa arab sebagai bahasa kitab tersebut. Oleh karenannya dengan mepelajari kitab kuning seorang santri yang telah menamatkan pembelajaran di pesantren cenderung memiliki pengetahuan bahasa arab. Sehingga ketika santri sudah menyelesaikan belajarnya, disamping mampu untuk memahami isi kitab dan sekaligus juga mampu menerapkan bahasa kitab tersebut menjadi bahasanya.

Sisi lain disamping tercapainya tujuan pembelajaran kitab kuning yaitu dengan tercapainya kemapuan memahami isi kitab dan menguasai bahasa arab sebagai bahasa kitab oleh para santri. Pembelajaran kitab kuning bertujuan untuk menanamkan rasa kebersamaan antara sesame santri dan para kiai yang membimbingnya. Hal yang demikian itu menghilangkan stratifikasi dalam pesantren, yakni antara kia yang dituakan dan santri yang merupakan yang diberi pelajaran dalam pesantren.

Dalam mempelajari kitab kuning setidaknya ada ilmu yang perlu dipelajari oleh seorang santri, diantaranya yang paling penting bahkan hukumnya wajib untuk dikuasai oleh santri selama belajar kitab kuning adalah ilmu Nahwu dan Shorof. Nahwu adalah kosa kata Bahasa Arab yang digunakan untuk mengetahui bentuk kata dan keadaannya ketika masih satu kata (Mufrod) atau ketika sudah tersusun (Murokkab). Termasuk yang ada didalamnya adalah pembahasan tentang Shorof. Ilmu Shorof merupakan bagian dari Ilmu Nahwu, yang lebih terfokus kepada pembahasan bentuk kata dan keadaannya ketika menjadi mufrod. Pembahasan Nahwu mencakup penjelasan tentang bentuk kata dan keadaannya ketika belum tersusun (mufrod), semisal bentuk Isim Fa'il mengikuti wazan فاعل, Isim Tafdhil mengikuti wazan المُرَكَّبَ. Akan tetapi tidak dapat dipungkiri, bahkan sudah menjadi aksioma bagi mayoritas santri bahwasanya ketika belajar ilmu nahwu dan shorof para santri merasa sangat sulit bahkan sering dijadikan momok. Hal ini disebabkan karena dalam belajar ilmu nahwu dan shorof terdapat banyak istilah-istilah yang dirilis oleh para nahwiyyin mulai dari zaman klasik sampai modern sedemikian banyak sehingga ilmu ini terkesan sulit untuk dipelajari. 
Terkadang ilmu ini ambigu, tidak konsisten, multi tafsir dan sulit untuk dicari padanan katanya dalam bahasa ibu. Problem multi istilah inilah yang menjadi problem dasar mengapa ilmu nahwu dan shorof dangat sulit untuk dipelajari.

Pondok Pesantren Al-Bidayah yang beralamatkan di Desa Tegal Besar Kecamatan Kaliwates Kabupaten Jember merupakan salah satu pesantren yang sukses dalam mengimplementasikan pembelajaran Nahwu Shorof nya. Keberhasilan pembelajaran ini tidak lepas dari strategi handal yang diterapkan oleh sang Kiai yaitu Dr. KH. Abdul Haris, M.Ag dalam memformulasikan pembelajarannya, sehingga dari strategi tersebut dihasilkan output yang berkualitas melalui upaya yang telah dilakukan kiai baik melalui Metode Pembelajaran dan buku-buku karya beliau yang menjadikan pembelajaran ilmu nahwu dan shorof menjadi ilmu yang mudah untuk dipelajari.

Dari observasi yang telah dilakukan, setidaknya dalam waktu sekitar 6-9 bulan mayoritas santri Pondok Pesantren Al-Bidayah telah menghafal, memahami dan mampu mempraktikkan ilmu nahwu dan shorof yang dipelajari di dalam teks arab atau kitab kuning terutama dalam kitab Al-Jurumiyah yang selanjutnya dilakukan penerapan juga pada kitab lain seperti Kitab Fathul Qorib, Ushul Fiqh, Mafahim Yajibu An-Tushohah dan kitab-kitab lain . Melihat fenomena tersebut, tentu strategi yang dilakukan oleh Dr. KH. Abdul Haris, M.Ag sangat menarik untuk dikaji dalam melakukan pembelajaran nahwu shorof. Terlebih lagi melihat antusias santri dalam belajar nahwu dan shorof dalam pondok pesantren AiBidayah sangat tinggi. Atas dasar itulah perlu dilakukan sebuah kajian yang berjudul "Strategi Kiai dalam Mensukseskan Pembelajaran Nahwu dan Shorof di Pondok Pesantren Al-Bidayah Tegalbesar Kaliwates Jember" yang nantinya bertujuan untuk mengetahui Strategi apa yang digunakan oleh kiai agar para santri mudah dalam menguasai pembelajaran nahwu dan shorof.

\section{B. Metode penelitian}

Penelitian ini mendeskripsikan tentang strategi kiai dalam mensukseskan pembelajaran ilmu nahwu dan shorof yang jenis penelitiannya menggunakan penelitian kualitatif dengan pendekatan kualitatif descriptive. Penelitian ini menggunakan pendekatan kualitatif deskriptif, karena hasil penelitian berupa data deskriptif dalam bentuk kata tertulis atau lisan dari perilaku orang-orang yang diamati (interview, observasi dan dokumentasi) serta hal-hal lain yang berkaitan dan diperlukan dalam penelitian. Penelitian ini mengambil lokasi di Pondok Pesantren Al-Bidayah Tegalbesar Kaliwates Jember dengan pertimbangan bahwa di pondok pesantren ini memiliki metode yang mampu mengantarkan santrinya 
dengan cepat menghafal, memahami dan mempraktikkan ilmu nahwu dan shorof yang dipelajarinya. Subyek penelitian kali ini adalah Pengasuh Pondok Pesantren Al-Bidayah, Pengurus dan Santri Pondok Pesantren Al-Bidayah. Subjek penelitian ini menggunakan teknik purposive sampling yaitu, pengambilan sampel sumber data dengan pertimbangan bahwa orang tersebut dianggap paling tahu tentang obyek/situasi sosial yang akan diteliti khususnya tentang peningkatan profesionalisme di Lembaga pendidikan tersebut. Metode pengumpulan data yang digunakan meliputi metode observasi, wawancara mendalam (in dept Interview ), dan dokumentasi. Analisis data dan pengecekan keabsahan data pada penelitian ini menggunakan teori yang dikemukakan oleh Miles dan Huberman bahwa proses analisa data terbagi menjadi tiga tahapan, yaitu Reduksi Data (Data Reduction), Penyajian Data (Data Display), dan Penarikan Kesimpulan dan Verifikasi (Conclusion Drawing and Verification). Dalam pengujian keabsahan data yang diperoleh, peneliti menggunakan teknik triangulasi yaitu teknik keabsahan data yang memanfaatkan sesuatu yang lain di luar data itu untuk keperluan pengecekan atau sebagai pembanding terhadap data itu. Teknik trianggulasi yang digunakan untuk menguji keabsahan data dalam penelitian ini adalah triangulasi sumber, dan triangulasi metode.

\section{Hasil dan Pembahasan}

1. Konsep Strategi Kiai

Strategi atau "strategia atau strategos" secara bahasa berasal dari bahasa Yunani (Greek) yang berarti "general or generalship" yang berarti sesuatu yang berkaitan dengan top manajemen pada suatu organisasi. Sedangkan secara istilah menurut Jauch dan Glueck (1988) menyatakan bahwa "unified, comprehensive, and integrated plan that relates the strategic adventeges of the firm to the challenges of the environment. It is design to the ensure that the basic objective of the are achieved through proper execution by the organization" Yang berarti strategi merupakan "rencana terpadu, komprehensif, dan terintegrasi yang menghubungkan keunggulan strategis organisasi dengan tantangan lingkungan. Hal ini dirancang untuk memastikan bahwa tujuan utama organisasi dapat tercapai melalui pelaksanaan yang tepat oleh suatu organisasi.

Implikasi dari eksistensi strategi tersebut adalah sebagai sarana untuk mencapai tujuan akhir (sasaran). Strategi dimulai dengan konsep penggunaan sumber daya organisasi secara efektif dalam suatu lingkungan yang berubah-ubah. Dengan kata lain, suatu tujuan dapat berhasil apabila antara perencanaan dan pelaksanaan strategi berjalan dengan baik (Akdon: 2009:14). 
Sedangkan Kiai adalah seseorang yang mempunyai pondok pesantren serta menguasai pengetahuan agama dan secara konsisten mampu menjalankan ajaran agama yang dikuasainya. Dalam Sebutan yang lain, kiai juga ditujukan kepada orang yang memahami ilmu agama, tanpa memiliki pondok pesantren atau tidak tinggal dan mengajar di pondok pesantren. Pengertian Kiai yang kedua tersebut mengajarkan ilmu agama dengan cara berdakwah atau berceramah dari desa ke desa, menyampaikan fatwa kepada khalayak masyarakat secara luas. Pada pondok pesantren, kiai merupakan elemen yang memiliki kedudukan paling esensial, kiai merupakan pendirinya. Sehubungan dengan itu, sudah sewajarnya jika pertumbuhan dan berkembangnya sebuah pesantren sangat bergantung kepada kepiawaian pribadi kiainya. Mayoritas kiai memiliki anggapan bahwa pondok pesantren diibaratkan sebagai kerajaan kecil di mana posisi kiai merupakan sumber mutlak dari kekuasaan dan kewenangan (power of authority) dalam kehidupan dan lingkungan pesantren. Seorang santri atau orang lain tidak akan mampu melawan kekuasaan kiai (dalam lingkungan pesantrennya) melainkan kiai lain yang pengaruhnya lebih besar. Kiai melalui kelebihan pengetahuannya, terutama terhadap pemahaman agama Islam, seringkali anggap sebagai orang yang paham akan keagungan Tuhan dan rahasia alam, oleh karenanya para kiai oleh masyarakat secara umum dianggap memiliki kedudukan yang strategis. Dalam beberapa kesempatan, Kiai menunjukkan kekhususannya dalam bentuk pakaian yang dikenakannya yang merupakan simbol kealiman. Meskipun seorang kiai memiliki peran yang sangat penting terutama dalam hal kepemimpinan, akan tetapi ketika berkaitan dengan sistem pendidikan yang ada di pesantren, unsurunsur pendidikan lain yang meliputi para ustadz, santri dan para pengurus juga termasuk elemen pendukung dalam sistem pendidikan pesantren (Mastuhu, 1994:25).

Menurut Syaiful Sagala kegiatan pembelajaran yang berlangsung di lembaga pendidikan pesantren bersifat fomal, disengaja, direncanakan, dengan bimbingan guru dan bantuan pendidik lainnya. Kegiatan pembelajaran pada dasarnya adalah upaya pengembangan potensi siswa melalui serangkaian kegiatan yang dilaksanakan secara berkesinambungan dan berkelanjutan untuk mencapai tujuan (Faishol, 2018). Apa yang hendak dicapai dan dikuasai oleh peserta didik dituangkan dalam tujuan belajar, disiapkan bahan apa yang harus dipelajari, dipersiapkan juga metode pembelajaran yaitu yang sesuai dengan bagaimana cara siswa mempelajarinya dan melakukan evaluasi untuk mengetahui kemajuan belajar siswa (Sagala, 2006:135). Dari penjelasan di atas bisa disimpulkan bahwasanya kiai merupakan pemimpin lembaga pendidikan, apa pun jenis atau 
coraknya. Sebab, kiai yang membawahi serta pengendali orang banyak sebagai bawahan yang secara struktural mengikuti langkah-langkah pemimpinnya dalam melaksanakan tugas-tugas kependidikan, mulai dari perencanaan hingga tahap evaluasi.

Dari penjabaran tersebut dapat dijelaskan bahwasanya yang dimaksud dengan strategi kiai adalah Rencana terpadu, komprehensif, dan terintegrasi yang dilakukan oleh seorang ahli agama yang mempunyai pondok pesantren guna malaksanakan atau menyebarkan ajaran agama yang dikuasainya dengan cara menghubungkan keunggulan strategis organisasi dengan tantangan lingkungan. Hal ini dirancang untuk memastikan bahwa tujuan utama organisasi dapat tercapai melalui pelaksanaan yang tepat oleh suatu organisasi.

\section{Konsep Nahwu dan Shorof}

Ilmu nahwu secara umum bertugas untuk menganalisis kedudukan i'rab sebuah kalimat dalam jumlah, sedangkan ilmu sharaf secara umum bertugas untuk menganalisis status kata (sighat) yang merangkai sebuah jumlah. Menurut Abubakar Muhammad Nahwu secara bahasa merupakan tata bahasa Arab (Gramatika Bahasa Arab), adapun secara istilah Nahwu adalah kaidah yang didalamnya menjelaskan bentuk bahasa Arab baik pada saat berdiri sendiri maupun dalam bentuk susunan kalimat. Menurut Syekh Musthafa al-Ghulayaini mendefinisikan Ilmu nahwu adalah ilmu yang mempelajari tentang suatu dasar, yang mana dengan dasar-dasar tersebut akan dapat diketahui bentuk-bentuk kalimat bahasa arab, baik dari segi perubahan harakat akhir suatu kalimat dan bina'nya (Ghalayainiy, 2008:4).

Adapun Ilmu Shorof secara etimologi adalah mengubah. Sedangkan secara istilah adalah berubahnya bentuk asal suatu kalimat kepada bentuk-bentuk lain untuk mendapatkan arti yang sesuai yang anya bisa dicapai dengan adanya perubahan (Anwar, 2000:1).

Untuk mensukseskan pembelajaran nahwu dan shorof kata kunci yang harus diperhatikan dalam pembelajaran qawaid, baik ilmu nahwu atau shorof adalah sistematis. Pengajaran ilmu qawaid yang tidak sistematis akan berdampak lompatan bepikir dan keruwetan yang berkepanjangan. Untuk dapat mensistematiskan materi ilmu qawaid dengan baik, sehingga mudah dicerna dan dipahami, seseorang harus paham terlebih dahulu pada karakter masing-masing bab yang terdapat dalam ilmu nahwu dan shorof (Haris, 2011: 3).

Di samping harus sistematis, pengajaran qawaid juga harus didasarkan pada asas manfaat. Seorang pendidik ilmu qawaid sebisa mungkin harus mengupayakan materi yang diajarkan dapat langsung dirasakan manfaatnya oleh 
peserta didik. Materi-materi yang tidak membumi atau jarang muncul dalam teksteks berbahasa arab sebisa mungkin pada tahap awal untuk ditinggalkan, karena peserta didik tidak dapat secara langsung merasakan manfaatnya yang pada akhirnya dapat berdampak pada kejenuhan, kebosanan dan bahkan ketidaksukaan terhadap materi-materi ilmu qawaid (Haris, 2011: 12).

\section{Strategi Kiai dalam Mensuksekan Pembelajaran Nahwu dan Shorof}

Pondok Pesantren Al-Bidayah yang beralamatkan di Desa Tegal Besar Kecamatan Kaliwates Kabupaten Jember merupakan salah satu pesantren yang sukses dalam mengimplementasikan pembelajaran Nahwu dan Shorofnya. Keberhasilan pembelajaran ini tidak lepas dari strategi handal yang diterapkan oleh sang Kiai yaitu Dr. KH. Abdul Haris, M.Ag dalam memformulasikan pembelajarannya, sehingga dari strategi tersebut dihasilkan output yang berkualitas melalui upaya yang telah dilakukan kiai baik melalui Metode Pembelajaran dan buku-buku karya beliau yang menjadikan pembelajaran ilmu nahwu dan shorof menjadi ilmu yang mudah untuk dipelajari.

Melalui strategi tersebut hampir mayoritas santri dalam waktu sekitar 6-9 bulan sudah mampu hafal, memahami dan mengalisis Nahwu dan Shorof ketika praktik membaca kitab kuning. Berikut ini strategi yang dilakukan oleh Kiai atau pengasuh pondok pesantren dalam mensukseskan pembelajaran Nahwu dan Shorof:

\section{a. Metode Pembelajaran}

Metode berasal dari bahasa Yunani. Secara etimologi, kata metode berasal dai dua suku perkataan, yaitu meta dan hodos. Meta berarti "melalui" dan hodos berarti "berjalan" atau "cara" (Ramayulis dan Nizar, 2009: 209). Metode pembelajaran merupakan cara yang dilakukan seorang pendidik untuk memudahkan peserta didik untuk memperoleh ilmu pengetahuan, menumbuhkan pengetahuan ke dalam diri penuntut ilmu dan menerapkannya dalam kehidupan (Nafi'dkk, 2007: 66).

Pendidikan adalah salah satu faktor yang sangat menentukan dan berpengaruh terhadap perubahan sosial (Rahman, 2018). Sebagai lembaga pendidikan, pondok pesantren dikategorikan sebagai lembaga pendidikan tradisional mempunyai sistem pembelajaran tersendiri yang kemudian menjadi ciri khas sistem pengajaran dibandingkan dengan sistem pembelajaran yang dilakukan di lembaga pendidikan formal.

Ada beberapa metode pembelajaran yang diberlakukan di pesantrenpesantren, diantaranya: Sorogan, weton/bandongan, halaqah, hafalan, Hiwar, 
bahtsul masa'il, fathul kutub, dan muqoronah. Seperti yang diungkapkan oleh (Subandriyo \& Faishol, 2019) dalam proses pembelajaran, penggunaan model pembelajaran dapat membantu tingkat pemahaman siswa, terutama dalam memahami konsep sehingga siswa menjadi lebih jelas dalam memahami suatu mata pelajaran tersebut. Metode-metode pembelajaran tersebut tentunya belum mewakili keseluruhan dari metode-metode pembelajaran yang ada di pondok pesantren, tetapi setidaknya paling banyak diterapkan di lembaga pendidikan tersebut.

1) Metode Sorogan

Sorogan secara terminologi berasal dari kata sorog (bahasa Jawa), yang berarti menyodorkan, sebab setiap santri menyodorkan kitabnya di hadapan kiai atau pembantunya (asisten kiai). Sedangkan pengertian sorogan secara etimologi adalah suatu metode yang ditempuh dengan cara guru menyampaikan pelajaran kepada santri secara individual, biasanya di samping di pesantren juga dilangsungkan di langgar, masjid atau terkadang malah di rumah-rumah (Qomar, 2007: 142). Sistem sorogan ini termasuk belajar secara individual, di mana seorang santri berhadapan dengan seorang guru, dan terjadi interaksi saling mengenal di antara keduanya. Sistem sorogan ini terbukti sangat efektif sebagai taraf pertama bagi seorang murid yang bercita-cita menjadi seorang alim.

2) Metode Wetonan atau Bandongan

Weton / bandongan, istilah weton secara terminologi berasal dari kata wektu (bhs. Jawa) yang berarti waktu, sebab pengajian tersebut diberikan pada waktu-waktu tertentu, yaitu sebelum dan atau sesudah melakukan shalat fardlu.. Sedangkan pengertian wetonan atau disebur dengan bandongan secara etimologi menurut Zamarkhsyari Dhofier yang dikutip Qomar adalah suatu metode pengajaran dengan cara guru membaca, menterjemahkan, menerangkan dan mengulas buku-buku Islam dalam bahasa Arab sedang sekelompok santri mendengarkannya (Qomar: 2007:143)

3) Metode Halaqoh

Metode halaqoh merupakan kelompok kelas dari sistem bandongan. Halaqah yang arti bahasanya lingkaran murid, atau sekelompok siswa yang belajar di bawah bimbingan seorang guru atau belajar bersama dalam satu tempat. Halaqah ini juga merupakan diskusi untuk memahami isi kitab, bukan untuk mempertanyakan kemungkinan benar salahnya apa-apa yang diajarkan oleh kitab, tetapi untuk memahami apa maksud yang diajarkan oleh kitab. 
Dalam pelaksanaannya, para santri dengan bebas mengajukan pertanyaanpernyataan ataupun pendapatnya. Dengan demikian, metode ini lebih menitikberatkan pada kemampuan perseorangan di dalam menganalisis dan memecahkan suatu persoalan dengan argumen logika yang mengacu pada kitab-kitab tertentu.

4) Hafalan

Hafalan adalah sebuah metode pembelajaran yang mengharuskan murid mampu menghafal naskah atau syair-syair dengan tanpa melihat teks yang disaksikan oleh guru. Dalam metode hafalan para santri diberi tugas untuk menghafal materi tertentu dalam jangka waktu tertentu. Hafalan yang dimiliki santri ini kemudian di"setorkan" di hadapan kiai atau kiainya secara periodik atau insidental tergantung kepada petunjuk sebelumnya.

5) Metode Peer Tutoring

Suherman (2003: 1) menyatakan bahwa metode Tutor Sebaya/Peer Tutoring adalah suatu metode dimana sekelompok siswa yang telah tuntas terhadap materi pelajaran memberikan bantuan kepada siswa yang mengalami kesulitan atau dalam memahami bahan pelajaran yang dipelajarinya. Metode pembelajaran ini lebih mengutamakan peran siswa dalam kegiatan pembelajaran serta kerjasama dengan kelompok lain secara heterogen tanpa menghilangkan tanggung jawab kepada setiap individu.

Metode pembelajaran merupakan cara yang dipersiapkan dan kemudian dilaksanakan oleh para pendidik agar proses pembelajarannya berjalan sesuai dengan tujuan yang ingin dicapai. Dalam rangka memudahkan santri menyerap materi yang diajarkan dan tercapainya tujuan pembelajaran yang telah ditetapkan, di sini kiai dituntut bisa memilih suatu metode yang tepat dalam pembelajarannya.

Metode pembelajaran yang digunakan di pondok pesantren Al-Bidayah ada yang bersifat tradisional, artinya metode tersebut memang sejak dahulu sudah diterapkan oleh pondok pesantren di seluruh Indonesia, seperti wetonan dan sorogan dan lain-lain. Selain itu, ada juga metode yang bersifat modern dengan pengertian metode baru yang dimasukkan ke dalam pembelajaran lembaga pondok pesantren berdasarkan atas pendekatan ilmiah. Seperti metode tutorial sebaya atau Peer Tutoring.

Dalam menentukan metode pembelajaran, yang diperhatikan oleh pengasuh pondok pesantren Al-Bidayah antara lain:

a. Tujuan yang hendak dicapai

Dalam setiap pembelajaran pasti ada tujuan yang hendak dicapai, dan tujuan pada masing-masing mata pelajaran pun juga berbeda-berbeda. Sehingga 
pencapaian tujuan merupakan suatu prioritas yang harus diperhatikan dan di kedepankan dalam memilih dan menetapkan metode apa yang akan dipakai dalam pembelajaran.

b. Kondisi santri

Setiap santri di dalam memahami suatu keilmuan memiliki kemampuan yang berbeda-beda, ada yang memiliki kemampuan yang baik dan ada pula yang buruk dalam memahami ilmu. Oleh karena itu, dalam menerapkan suatu metode pembelajaran, seorang pendidik juga harus memperhatikan kondisi para santri.

\section{c. Fasilitas yang tersedia}

Tersedianya sarana dan prasarana atau media pembelajaran memiliki peran yang sangat penting. Tanpa tersedianya fasilitas tersebut, penggunaan metode yang sudah direncanakan akan terkendala sehingga pemahaman santri ketika memahami materi pembelajaran pun kurang maksimal.

Berikut ini metode pembelajaran yang diterapkan di pondok pesantren $\mathrm{Al}$ Bidayah untuk mempercepat hafalan dan pemahaman santri dalam pembelajaran nahwu shorof:

1. Wetonan yaitu suatu metode pengajaran dengan cara guru membaca, menterjemahkan, menerangkan dan mengulas buku-buku Islam dalam bahasa Arab sedang para santri menyimak kitab dan mencatat infomasi-informasi penting yang diperoleh dari penjelasan kiai. Adapun waktu pelaksanaan metode ini di pondok pesantren Al-Bidayah dilaksanakan sesudah ba'da sholat shubuh yaitu ketika memberikan keterangan tentang isi suatu kitab yang memang dirasa sulit oleh santri baik dari aspek i'rab maupun arti dari teks yang sedang dibahas.

2. Sorogan yaitu metode pembelajaran yang ditempuh dengan cara guru menyampaikan pelajaran kepada santri secara individual, di mana para santri membawa kitab yang sudah dipelajari atau dihafalkan secara mandiri. Dalam metode ini santri dituntut bisa membaca kitab (dari segi i'rabnya) dengan benar, selain itu santri juga dituntut untuk bisa menjelaskan maksud dari isi kitab yang sedang dibaca.

3. Hafalan yaitu metode pembelajaran yang mengharuskan murid mampu menghafal istilah-istilah nahwu dengan tanpa melihat teks yang disaksikan oleh kiai. Metode ini merupakan metode yang paling sering diterapkan dalam pembelajaran di pondok pesantren Al-Bidayah. pelaksanaannya antara lain pada pembelajaran Nahwu dasar, al-Jurumiyah (bagi santri yang telah nahwu dasar), sharaf dan kitab Fathu al-Qarib al-Mujib . 
4. Tutorial sebaya atau Peer Tutorial yaitu metode pembelajaran terhadap kelompok kecil yang dilakukan melalui proses bimbingan yang diberikan/dilakukan oleh santri yang sudah menghafal materi dengan baik kepada santri baik secara perorangan atau kelompok kecil yang masih belum menguasai materi dengan baik. Metode ini di pondok pesantren Al-Bidayah dilakukan secara face to face yang dipakai pada pembelajaran nahwu dasar.

\section{b. Pembuatan Buku Teks}

Menurut Crowther (1995: 1234) yang dimaksud dengan textbook adalah a book giving instruction in a subject used especially in schools. Yang berarti bahwa sebuah buku yang dapat memberikan intrusi pada suatu subjek mata pelajaran terutama di sekolah. Sedangkan menurut Tarigan dan Tarigan (1986: 13) buku teks merupakan buku mata pelajaran dalam bidang studi yang memiliki maksud dan tujuan tertentu, disusun oleh pakar pada bidang keahliannya yang didalamnya dilengkapi sarana pembelajaran yang sesuai agar mudah dipahami oleh para pemakainya baik di sekolah ataupun perguruan tinggi sehingga dapat menunjang pelaksanaan pembelajaran.

Ada empat dasar yang dijadikan dalam mengklasifikasikan buku teks, yaitu:

1. Sesuai dengan mata pelajaran atau bidang studi

2. Sesuai dengan mata kuliah yang ditempuh

3. Sesuai dengan penulisan buku teks

4. Sesuai dengan penulis buku teks

Buku teks dapat dikatakan berkualitas apabila aspek materi, grafika, penyajian dan kebahasaannya sesuai dengan tujuan pembelajaran yang terdapat pada kurikulum, selain itu juga harus terintegrasi dengan pelajaran lain namun tetap menghargai hal-hal yang tidak bertentangan seperti agama.

Selain aspek materi, penyajian materi dalam buku teks harus memenuhi syarat lain yaitu sistematis karena dengan materi yang sistematis peserta didik akan lebih mudah memahami pengetahuan sesuai dengan umur peserta didik.

Strategi Kedua yang dilakukan oleh Kiai Pondok Pesantren Al-Bidayah dalam mensukseskan pembelajaran Nahwu dan Shorof adalah dengan menyusun buku teks yang selanjutnya buku tersebut dijadikan sebagai acuan para santri dalam menghafalkan, memahami dan menganalisis teks arab.

Setidaknya ada 7 (Tujuh) buku pedoman yang sudah diterbitkan oleh Dr. KH. Abdul Haris, M.Pd selaku pengasuh Pondok Pesantren Al-Bidayah Yaitu:

a. Nahwu dan shorof tingkat pemula: Buku ini berisi materi pokok nahwu yang bersifat dasar bagi para pemula yang oleh pengasuh pondok pesantren Al-Bidayah disusun secara sistematis, harapannya para santri maupun para 
pembaca sangat mudah dalam mencerna, memahami dan menghafalkan ilmu nahwu.

b. Nahwu dan shorof tingkat lanjut: buku ini merupakan lanjutan dari buku nahwu dan shorof tingkat pemula. Kelebihannya adalah terdapat beberapa istilah-istilah tambahan yang penting dalam memahami ilmu nahwu.

c. Tanya jawab nahwu dan shorof: Buku ini mengulas materi nahwu dan shorof dengan cukup komprehensif dalam bentuk tanya jawab, selain itu buku ini juga dilengkapi dengan signifikansi materi, tabel, contoh serta cara analisanya

d. Aplikasi I'rab: buku ini mengajari para santri dan pembaca untuk bisa menentukan kedudukan I'rab secara tepat. Karena dalam menganalisis sebuah lafadz peserta didik dituntut untuk memiliki akurasi yang ideal dalam menentukan kedudukan I'rab. Buku ini menjadi penting karena didalamnya ditawarkan model pembacaan yang sistematis dalam menganalisis teks arab yang dikemas dalam bentuk contoh-contoh mulai dari yang sederhana sampai contoh yang paling sulit dan kompleks.

e. Logika analisa teks arab: buku ini mengulas tentang bagaimana cara berlogika yang mudah pada saat bertemu teks arab. Yang didalamnya tersaji materi tentang filosofi dan fungsi dari masing-masing teori dalam ilmu nahwu, logika ketika bertemu dengan teks arab dan cara menyelesaikan problematika aplikasi dari teori.

f. Panduan Pertanyaan Nahwu dan Shorof: buku ini berisi pertanyaanpertanyaan yang nantinya bisa digunakan sebagai alat untuk mempermudah peserta didik dalam memahami ilmu nahwu secara sistematis.

g. Ringkasan teori dasar Nahwu: buku ini merupakan sebuah buku saku yang di dalamnya berisi ringkasan dari buku teori dasar nahwu dan shorof pemula. Harapannya peserta didik lebih dimudahkan dalam memahami dan mengahafalkan teori dasar nahwu kapanpun dan dimanapun.

Buku yang ditulis oleh oleh Kiai Pondok Pesantren Al-Bidayah masuk kategori buku yang mudah dipahami karena dalam penulisannya pengasuh melakukan sistematisasi sehingga para santri sangat mudah untuk menghafal, mencerna dan memahami nahwu dan shorof.

\section{SIMPULAN}

Agar mampu memahami teks arab atau kitab kuning, seorang santri dituntut terlebih dahulu memahami ilmu gramatika bahasa arab atau yang biasa 
disebut dengan ilmu nahwu dan shorof. Akan tetapi, sudah menjadi aksioma bahwasanya ketika belajar ilmu nahwu dan shorof para santri merasa sangat sulit bahkan sering dijadikan momok. untuk mensukseskan pembelajaran nahwu tersebut tentunya peran serta pengalaman seorang kiai dalam mencari strategi sangat diperlukan.

Pondok pesantren Al-Bidayah pada saat ini terkenal dengan pondok pesantren yang sukses dalam pembelajaran ilmu nahwu dan shorof. Hal ini terbukti di mayoritas santrinya yang hanya membutuhkan waktu sekitar 6-9 bulan sudah mampu dalam menghafal, memahami dan mempraktikkan ilmu nahwu dan shorofnya ketika menganalisis teks Arab.

Diantara strategi yang digunakan kiai di pondok pesantren Al-Bidayah adalah (1) metode pembelajaran: kiai dalampembelajaran nahwu dan shorof memadukan metode tradisional dan modern berdasarkan pengalaman kiai selama menjadi seorang pendidik. Metode yang dipakai selama ini oleh kiai adalah metode Wetonan, Sorogan, Hafalan dan Peer Tutorial. (2) Penyusunan buku teks: buku ini merupakan karya dari kiai Pondok Pesantren Al-Bidayah yang selanjutnya dijadikan sebagai pedoman penting untuk mengahafalkan dan memahami ilmu Nahwu dan Shorof. ada tujuh buku karya kiai Pondok Pesantren Al-Bidayah, yaitu: Nahwu dan shorof tingkat pemula, Nahwu dan shorof tingkat Lanjut, Tanya jawab nahwu dan shorof, Aplikasi I'rab, Logika analisa teks arab, Panduan Pertanyaan Nahwu dan Shorof dan Ringkasan teori dasar Nahwu.

\section{DAFTAR RUJUKAN}

Akdon. (2009). Strategic Management For Education Management (Manajemen Strategik untuk Manajemen Pendidikan). Bandung: Alfabeta.

Al-Ghulayaini, Al-Adib Mushthafa Bin Muhammad bin Salim. Jami' Al-Durus AlArabiyah. Beirut: Darul Kutub Al-Ilmiyyah, t.t

Anwar, Moch. (2000). Revisi Ilmu Shorof Terjemahan Matan Kailani dan Nadhom AlMaqsud berikut Penjelasannya. Bandung: Sinar Baru Algesindo

Crowther, J. R. (1995). Theory and Practice. 42. New Jersey : Humana Press 
Erman, Suherman. Dkk. (2001). Strategi Pembelajaran Matematika Kontemporer. Bandung Jica

Glueck, W.F. dan Lawrence, R.J. (1989). Manajemen Strategi dan Kebijakan Perusahaan. Edisi Ketiga. Terjemahan Murad dan Henry Sitanggang. Jakarta: Penerbit Erlangga

Guntur Tarigan, Henry. (1986). Menyimak Sebagai Suatu Keterampilan Berbahasa. Angkasa Bandung

Haris, Abdul. (2011). Strategi Pembelajaran \& Konsep Fi'il. Jember: STAIN Jember

Mastuhu. (1994). Dinamika Sistem Pendidikan Pesantren. Jakarta: INIS

Nafi', M. Dian, Abd A'la, Hindun Anisah, Abdul Aziz dan Abdul Muhaimin. (2007). Praksis Pembelajaran Pesantren.Yogyakarta: PT LKiS Pelangi Aksara

Noor, Mahpuddin. (2006). Potret Dunia Pesantren. Bandung: Humaniora

Peraturan Menteri Agama (PMA) Nomor 13 Tahun 2014 tentang Pendidikan Keagamaan Islam

Qomar, Mujamil. (2005). Pesantren: dari transformasi metodologi menuju demokratisasi instuisi. Jakarta: Erlangga

Ramayulis dan Samsu Nizar. (2009). Filsafat Pendidikan Islam Telaah Sistem Pendidikan dan Pemikiran Para Tokohnya. Jakarta: Kalam Mulia

Sagala, Saiful. (2006). Konsep dan Makna Pembelajaran. Bandung: Alfabeta

Sugiyono. (2008). Memahami Penelitian Kualitatif. Jakarta: Alfabeta

Sugiyono. (2014). Metode Penelitian Kuantitatif Kualitatif dan R\&D. Bandung: Alfabeta 
Suharsimi, Arikunto. (2009). Prosedur Penelitian: Suatu Pendekatan Praktek. Jakarta: Rineka Cipta.

Faishol, R. (2018). Pengembangan Paket Pembelajaran Ilmu Pengetahuan Sosial (IPS) Kelas IV Menggunakan Model Dick, Carey \&amp; Carey di SD Negeri 2 Tamanagung. Tarbiyatuna : Kajian Pendidikan Islam, 2(2), 31-49. Retrieved from

http://ejournal.iaiibrahimy.ac.id/index.php/tarbiyatuna/article/view/16

Rahman, K. (2018). Perkembangan Lembaga Pendidikan Islam di Indonesia.

Tarbiyatuna: Kajian Pendidikan Islam, 2(1), 1-14.

Subandriyo, S., \& Faishol, R. (2019). Penerapan Model Pembelajaran Kooperatif Tipe Scramble Untuk Meningkatkan Hasil Belajar Siswa Kelas XI SMA Al Hikmah. Tadrisuna : Jurnal Pendidikan Islam Dan Kajian Keislaman, 2(1), 1932. Retrieved from http://ejournal.stitradensantri.ac.id/index.php/tadrisuna/article/view/18

Wahyono, I. (2017). Peran Kiai Dalam Mensukseskan Pembelajaran Kitab Kuning. AL-WIJDÁN: Journal of Islamic Education Studies, 2(2), 41-53. 